\title{
Domestic Institutional Design and the National Interest in Trade Negotiations ${ }^{1}$
}

\section{Dr. Vinícius G. Rodrigues Vieira (Associate Professor of Economics and IR, FAAP) rodriguesvieira@gmail.com, vgvieira@ faap.br}

Word Count: 13,056

\begin{abstract}
How do different domestic institutional settings affect the formation of the national interest in trade negotiations? While current evidence suggests that institutions influence such a process even when societal groups dominate policymaking and international factors limit state choices, it remains unclear to what extent the domestic institutional design shape bureaucrats' perceptions on both internal and foreign constraints. Building upon Brazil's and India's cases in World Trade Organization's (WTO) Doha Round between 2003 and 2008, I address that question through process-tracing with the purpose of theory-building. I focus the analysis on the nodal bureaucracy, understood as the institution at the forefront of international bargaining. I argue that if such a bureaucracy is responsible for diplomacy in general, foreign factors prevail in decision-making. In turn, if the nodal bureaucracy is devoted only to traderelated issues, domestic economic factors dominate policymaking. The Brazilian Ministry of Foreign Affairs and the Indian Ministry of Commerce and Industry represent those two ideal types respectively. I reach the conclusions using qualitative methods, triangulating the information of 99 elite interviews with archival and secondary sources. The findings suggest that decisions depend on how institutions that participate on foreign affairs are embedded in the domestic and the international level.
\end{abstract}

Keywords: Domestic Institutional Design, Foreign Policy, Trade Policy, WTO, Brazil, India

\footnotetext{
${ }^{1}$ This paper is derived from the doctoral thesis "The Players in the fields : national identity and the politics of domestic preferences of Brazil and India in the Doha Development Round (2001-2008)", successfully presented at Nuffield College, University of Oxford, on July 16, 2014. This version was prepared on March 2016.
} 


\section{Introduction}

Trade negotiations are two-level games (Putnam 1988), implying that diplomats face domestic and international constraints when negotiating. Policymakers, therefore, must make compromises in the process of elaborating the national interest, here conceived as the set of preferences a state espouses in a given issue-area, such as trade. In doing so, bureaucrats and elected officials disagree with each other while facing pressure from business groups and non-governmental organizations (NGOs) and also may disagree with each other. Meanwhile, the international context may be perceived differently by various actors: in trying to understand a scenario, policymakers usually resort to ideas (Keohane and Goldstein 1993). However, diplomats and other officials in charge of crafting a country's stances in negotiations are embedded in institutional settings (Allison 1971) located in the interstice of the fluid divide between the domestic and the international levels (Chorev 2007). Such a fact prompts a question: how do distinct institutional designs (Arel-Bundock et al. 2015) impact the formation of the national interest in trade negotiations? That is, do differences in the manner state bureaucracies are embedded in the broader social environment and interact with each other explain variance across the national interest of different negotiating parts?

This article offers an answer to those questions through the development of two ideal types of bureaucracies devoted to trade negotiations. I argue that the main bureaucracy responsible for trade negotiations decisively impacts the formation of the national interest. Such an institution - henceforth called nodal bureaucracy - corresponds to the section of the state that coordinates policymaking in a negotiation, dealing with domestic inputs and representing the state in diplomatic summits. If the nodal bureaucracy is responsible for foreign policy in general, it is more embedded in the international level than in the domestic one, leading foreign factors non-related to economic issues to prevail in decision-making. Alternatively, if the nodal bureaucracy is devoted to economic issues only, domestic interests become the driving force in shaping bureaucrats' mindset. The distinction generates the two ideal types: looking-abroad bureaucracies, which are more susceptible to foreign factorsincluding concerns related to high-politics-, and looking-inside bureaucracies, which are more sensitive to the domestic dynamic of power-in particular pressures from interest groups. While policymakers can deliberately change institutions, the latter evolve in directions not foresaw by their creators (Pierson 2000). Therefore, the institutional design has independent consequences upon the way the state interacts with domestic and international constraints and, thus, formation of the national interest. Here I build upon Krasner's (1978: 
35) notion of national interest, corresponding to general goals that decision-makers set, but not to particular preferences of interest groups or office-holders. ${ }^{2}$

I develop the argument through a paired comparison (George and Bennett 2005) that, following the model of Beach and Pedersen (2013: 17), involves process tracing with the purpose of theory-building. The model implies in first building a conceptual framework and later demonstrating its operationalization and empirical application, following the idea that induction is a key element of theorizing in IR (Blagden 2016). With such a purpose, I study the cases of Brazil and India in the negotiations of World Trade Organization's (WTO) Doha Round and its Development Agenda (DDA) between 2003 and 2008. The Brazilian and Indian cases approximate the looking-abroad and the looking-inside ideal types, respectively. In Brazil, the Ministry of Foreign Relations (MRE) is in charge of diplomacy in general and defends the liberalization of agricultural markets as a means of enhancing Brazil's position in international politics and soft-balancing (Hurrell 2006) the dominance of the European Union (EU) and the United States (US) in global economic governance. By contrast, the Ministry of Commerce and Industry (MoC) led the negotiations in India. The MoC has direct links with domestic interest groups and is subject to domestic political demands, in particular from bureaucracies and politicians associated to rural constituencies. ${ }^{3}$ As a result, Indian negotiators were concerned first and foremost with protecting certain vulnerable economic sectors, in particular small farmers who are dependent on subsides and barriers to imports. I reach the conclusions based upon 99 semi-structured interviews ${ }^{4}$ conducted with bureaucrats, office holders, members of business associations, and NGOs from the two countries under study, triangulated (Beach and Pedersen 2013: 123-143; Tarrow 2010, 108) with archival sources, and secondary literature.

Although the DDA is still under negotiation, I delimited the time-frame of the study in order to control for alternative explanations, thus allowing me to increase the analytical leverage in spite of working only with two cases. The year 2003 marks the rise of Brazil and India as main negotiating parts of the DDA, displacing Canada and Japan from the so-called Quad, also formed by the EU and the US. Furthermore, the failure of concluding the 2008

\footnotetext{
${ }^{2}$ For a different definition, see Milner 1997.

${ }^{3}$ According to 2011 Indian Census, 68.84 percent of the country's 1.2 billion inhabitants live in rural areas, against 31.16 living in cities (Census of India 2011).

${ }^{4}$ For the sake of brevity, I cite only the most representative interviews. The interviews not directly quoted were, however, used for background information.
} 
July Mini-Ministerial Meeting in Geneva represents the main deadlock that the negotiating parts of the DDA faced before the beginning of the global financial crisis (Jones 2010; Narlikar and Van Houten 2010: 142). Since then, the prospects for effective multilateral liberalization of trade diminished significantly. Apart from being the most active negotiating parts representing interests from outside the $\mathrm{West}^{5}$ in the DDA (Hopewell 2015), Brazil and India have other characteristics that allow them to be placed in a paired comparison, following the logic of the most similar systems design (Faure 1994). In the domestic level, both countries started the liberalization of their economies almost at the same time (in 1990 and 1991 respectively) and have negotiating bodies with autonomy (following Carpenter 2001 definition) and technical expertise. In the international level, they never aligned themselves automatically with the West in international regimes. Specifically in the multilateral system of trade, Brazilian and Indian diplomacy have historically contested European and US dominance even under the period of the General Agreement on Trade and Tariffs (GATT, 1947-1994), before the creation of the WTO (Narlikar and Tussie 2004).

Brazil's defense of liberalization and India's protectionist stances are puzzling under alternative frameworks based on ideas, organization of interests, government preferences, and current institutional accounts. For each case, those explanations predict the opposite set of national interest. In Brazil, MRE supposed autonomy vis-à-vis interest groups and historical alignment with the old import substitution industrialization (ISI) paradigm (Sikkink 1991) within a context of strong organization of manufacturing interests and economic debate pervaded by neo-developmental ideas (Ban 2013) would predict the defense of protectionism. By contrast, sectors with offensive interests in India (i.e., information and communication technology services, ICTs) had a better lobbying organization than those with protectionist demands (i.e., subsistence agriculture), having direct access to MoC bureaucrats. In turn, they have been aligned with liberalization since the opening of Indian markets. Therefore, the national interest should have leaned towards offensive demands.

With the looking-inside and looking-abroad typology, I contribute to the literature that discusses the weight of state institutions on decision-making in domestic-international phenomena (Farrell and Newman 2014). In negotiations, institutions are often considered as being mere intervening factors to channel domestic interests, changing the weight of those interests on the final set of positions a country defends (Ikenberry 1988). Alternatively,

${ }^{5}$ I conceive the West as the group of advanced industrial democracies located in North America and Western Europe, plus Australia, Japan, and New Zealand. 
evidence suggests that institutions empower certain sectors over others: segments with more connections with bureaucracies tend to prevail in the elaboration of trade policies (Ehrlich 2011). In addition, the literature already discussed the impact of bureaucracies' autonomy in relation to the executive power when implementing foreign policy (Arel-Bundock et al. 2015). Thus, the institutional design frames and therefore limits the views of decision-makers (Miles 1978). Yet it remains unclear how different bureaucracies interact with each other, as well as whether different institutional settings lead the "fluid divide" between domestic and international constraints to be perceived as generating distinct opportunities not only throughout time for a given country. ${ }^{6}$ To shed light on the question, one has to verify whether distinct institutional designs and patterns of interaction among bureaucracies render different perceptions for different states with similar characteristics in the same domesticinternational phenomenon, as it is the case of Brazil and India in the DDA negotiations.

The paper is organized as follows. In the first section, I explore the existing explanations for Brazil's and India's positions in the DDA negotiations. I consider institutional factors, interests, ideas, and government preferences. With this, I justify their selection as cases for developing the argument through an inductive strategy. Then in section two, I elaborate the looking-abroad and looking-inside ideal types and explain why the domestic institutional design is a relevant factor in explaining the national interest. In the third part, I analyze Brazilian and Indian positions in the DDA talks as I confront archival sources and elite interviews to make congruence tests for assessing the argument (Van Evera 1997). The conclusion discusses the external validity of the looking-abroad/inside typology and suggests new avenues of research.

\section{An Empirical Puzzle with Theoretical Implications}

I begin the analysis by outlining the puzzle on Brazil's and India's national interest in the DDA negotiations. Those states' demands in the round are contradictory if analyzed under frameworks based upon the organization of interests and collective action (e.g., Olson 1971), ideas (e.g., Keohane and Goldstein 1993), and partisan preferences of those who hold power (e.g., Sherman 2002). In discussing alternative explanations, I do not make an extensive review of the literature on the domestic origins of the national interest in trade, rather focusing on the application of conventional arguments to the Brazilian and Indian cases. As explained in the introduction, the paired comparison offers conditions for developing a

\footnotetext{
${ }^{6}$ For a research design as such, see Chorev's (2007) analysis of US.
} 
typology and a theory that accounts for the impact of domestic institutions upon the perceptions of negotiators.

\section{Brazil's Odd Embrace of Liberalization}

Brazil's offensive demands had as main goal expanding market access abroad for its commercial agriculture, particularly in developed countries, such as EU members and the US. This, however, meant a trade-off at the expense of industry, as the EU and the US demanded the removal of trade barriers in the developing world for their manufactured goods (Gallagher 2007: 76). "We knew that, in the round, industry would be sacrificed," summarizes a bureaucrat with close connections with the manufacturing sector. ${ }^{7}$ Such a trade-off is puzzling given that, although not as strong as it had been before economic liberalization (Bresser-Pereira 2009), industry remained an important sector for the Brazilian economy, at least as much as the emerging agribusiness segment (Hopewell 2013).

Conventional institutional arguments cannot explain Brazilian preference for liberalization. The MRE and the President (who retains the constitutional prerogative of conducting foreign affairs) considered diverse inputs in formulating foreign trade policy. The Ministry of Agriculture (MAPA) had links with agribusiness, while the Ministry of Development, Industry, and Foreign Trade (MDIC) provided a channel for defensive industrial interests. The supposed "natural" preference of the Brazilian state for defending agricultural exports therefore does not hold: both agricultural and industrial sectors had access to policymakers. Furthermore, the MRE was aligned with the import substitution project (Sikkink 1991), which is inconsistent with the diplomats' the country's supposed preference for liberalization in the DDA. Moreover, successive interactions with the WTO system supposedly enhanced Brazil's capacity to elaborate foreign trade policy (Shaffer et al. 2008). Yet, such was not the case of diplomacy in the DDA given that negotiators conceded too much in industry in exchange for market access in agriculture.

Interests do not provide insights into such a preference either, as both liberalizing and protectionist sectors lobbied the government during the DDA negotiations. Business organizations in industry had systematically been following foreign trade policymaking since mid-1990s, with the negotiations aimed at forming the Free Trade Area of the Americas (FTAA). In 1996, the National Confederation of Industry (CNI) founded the Brazilian Business Coalition (CEB) with the goal of influencing the government in the FTAA talks

\footnotetext{
${ }^{7}$ Author interview with senior bureaucrat, Brasília, 6 July 2012.
} 
(Mancuso and Oliveira 2006). The CEB along with the Federation of Industries of the State of São Paulo (FIESP)—where about 40 percent of Brazilian industrial production is based (SEADE 2012) - aggregated manufacturers' demands. ${ }^{8}$ Agricultural commodity exporters adopted the same strategy, with segments (e.g., beef and soya bean producers) being as active as the National Confederation of Agriculture (CNA). However, peasants and small agricultural producers took a different position and favored protection, as the activities of the National Confederation of Agricultural Workers (CONTAG) suggest, which was expected to counter the influence of large farmers.

In Brazil, the preference for favoring agriculture in the DDA is often explained by liberalizing economic ideas. Under such a view, the Brazilian economy had an inherent comparative advantage in agricultural commodities. However, in the first 13 years after liberalization in Brazil (1990-2003), industry's participation in exports of goods and services remained higher than that of the agricultural sector, contributing at least to 50 percent of all goods sold abroad (World Bank 2010). The Brazilian process of industrialization was one of the most successful industrializing experiences after the Second World War. Industrial output grew four times between 1965 and 1980. Such a rate is even higher than in Japan, which expanded three times in the same period. ${ }^{9}$ Also, when the DDA was launched, Brazil was moving towards an export-led strategy that included an emphasis on both agricultural commodities and manufactured goods (Rodrigues Vieira 2014), with domestic incentives to both segments (Ban 2013).

Finally, partisan preferences also do not provide a straightforward answer for Brazilian positions. The DDA negotiations started under Fernando Henrique Cardoso's government (1995-2003), whose Brazilian Social Democracy (PSDB) party was reputed to be more favorable to economic liberalization than his successor, President Luiz Inácio Lula da Silva of the Workers' Party (PT) (Ban 2013). Despite PT strong links with industrial workers and small peasants, prioritization of gains in agriculture continued under Lula. Moreover, during his presidential tenure, Brazil faced stronger competition from Chinese manufactures, and agricultural commodities began to dominate Brazilian exports.

\footnotetext{
${ }^{8}$ Sectorial associations, in particular of automobile, chemical, electrical, machinery, and textile segments, also played a crucial role in such a process.

${ }^{9}$ Calculated based on data collected by World Bank 2010.
} 


\section{The Resistance of Protectionism in India}

In contrast to Brazil's demand for liberalization, India's stances consisted of a more cautious approach, notwithstanding that this implied leaving aside the liberalizing interests of ICT services. The sector is one of the main winners in the process of economic liberalization, which was launched in 1991 (Mukherji 2013) and did not have as much negative impact on industry as initially predicted. Yet Indian negotiators resisted to the launch of the Doha Round in 2001 (Narlikar and Wilkinson 2004). In India, the protectionist stance seems to be predicted by conventional institutional explanations: government officials are responding to the concerns of India's large and politically influential peasantry. Nonetheless, the $\mathrm{MoC}$, the nodal bureaucracy, has direct connections with industrial and services lobbying groups (Narlikar 2008 and 2013). It interacts with other bureaucracies, in particular the Ministry of Agriculture (MoA), which sides with protectionist interests in the sector, and the Ministry of External Affairs (MEA). The MEA expanded its participation in economic diplomacy throughout the DDA negotiations, yet the MoC still coordinated decision-making, leading to the expectation that liberalizing positions had more weight in the national interest.

Nevertheless, the organizational strength of liberalizing interests amid increasing participation of non-state actors in trade policymaking renders puzzling the defense of protectionist positions. Industry and services had divided interests on the DDA. The software sector has a strong lobbying group, the National Association of Software and Services Companies (NASSCOM), with direct connections with the MoC. So do the two largest industrial federations of India, the Confederation of Indian Industry (CII) and the Federation of Indian Chambers of Commerce and Industry (FICCI). ${ }^{10}$ Sectorial organizations, as most interviewees agree, become more pro-active as liberalization consolidated. In fact, industry and ICTs are organized as a typical interest group. By contrast, small farming (one of the most defensive sectors) acted outside national associations.

During India's economic liberalization, most of services gained strength vis-à-vis agriculture. According to World Bank (2010) data, manufacturing remained with not less than one third of exports, while the share of services reached about 30 percent of the totalout of which 70 percent is related to ICTs. The primary sector, in turn, accounted in 2008 for less than 20 percent of GDP and exports. Therefore, under the point of view of India's early liberalizing experience and, thus, of economic ideas, no automatic alignment with

${ }^{10}$ There is also reference to the participation of the Associated Chambers of Commerce of India (ASSOCHAM) in such a process, but with far less prominence than CII and FICCI. 
protectionist stances could be expected. Indeed, most of Indian economic opening stem from domestic decisions rather than international pressure (Mukherji 2013: 365). Furthermore, specifically at the launch of the DDA negotiations, the concerns of the Indian government were less with agriculture and more with the so-called Singapore Issues (transparency in government procurement, trade facilitation, trade and investment, and trade and competition), which, in practice, ended up not being negotiated (Narlikar and Wilkinson 2004).

The positions of different coalitions that were in office between 2003 and 2008 do not solve the puzzle either. The National Democratic Alliance (NDA), led by the center-right, Hindu-nationalist Bharatiya Janata Party (BJP) and in office when the round was launched (1998-2004), was very committed to economic liberalization. In turn, the first reforms had been launched under a government led by the Indian National Congress (INC) (1991-1996) (Acharya 2002; Kohli 2009). When the United Progressive Alliance (UPA), headed by the INC, ascended to power in 2004, the post-liberalizing economic consensus remained. The only salient difference is that NDA aligned India with Brazil in the Cancun Ministerial, in September 2003, to counter the developed world's agenda that circumvented the demands of the Global South. ${ }^{11}$ The Agricultural G-20, a coalition composed of developing countries predominantly with offensive interests in agriculture (including Brazil), lost importance for India's diplomacy under the UPA administration. Instead, the government emphasized membership in the G-33, which advocated special treatment in agriculture for developing countries (Narlikar and Tussie 2004). Therefore, although with different nuances, both governments had protectionist concerns amid ambivalent actions towards further economic opening outside the DDA negotiations.

\section{$\underline{\text { Limits of Conventional Explanations }}$}

Table 1 summarizes the limitations of current frameworks in explaining Brazilian and Indian positions. Arguments based on institutions, organization of interests, ideas, and government preferences predict for each case the opposite set of national preferences demonstrated throughout the DDA negotiations. Whereas one expects Brazil to defend protectionist positions or at least balanced offensive and defensive demands, India had conditions to accept expansion of the scope of multilateral liberalization.

${ }^{11}$ Until the Cancun meeting in March 2003, the Quad, composed by the US, EU, Canada, and Japan dominated the negotiations in the multilateral system of trade. 
Table 1. Predicted Outcome of Brazil's and India's Preferences in the DDA Negotiations according to Conventional Explanations (2003-2008)

\begin{tabular}{|c|c|c|c|}
\hline \multirow{2}{*}{ Framework } & \multirow{2}{*}{ Hypothesis } & \multicolumn{2}{|c|}{ Predicted Outcome } \\
\hline & & Brazil & India \\
\hline Institutions & $\begin{array}{l}\text { Bureaucracies follow their } \\
\text { own views or are subject } \\
\text { to organized groups only }\end{array}$ & $\begin{array}{l}\text { Demand for protection, as the } \\
\text { MRE used to be a bulwark of } \\
\text { ISI interests in the country until } \\
\text { economic liberalization. }\end{array}$ & $\begin{array}{l}\text { Demand for liberalization, as } \\
\text { the MoC has connections with } \\
\text { organized interest groups and } \\
\text { is supportive of liberalization }\end{array}$ \\
\hline Organization of Interests & $\begin{array}{l}\text { Sectors with better } \\
\text { organization tend to lobby } \\
\text { more effectively }\end{array}$ & $\begin{array}{l}\text { Balance between liberalizing } \\
\text { and protectionist positions } \\
\text { given that sectors in both } \\
\text { coalitions were mobilized }\end{array}$ & $\begin{array}{l}\text { Prevalence of liberalizing } \\
\text { positions from industry and } \\
\text { services, the most organized } \\
\text { economic segments }\end{array}$ \\
\hline Ideas & $\begin{array}{l}\text { States tend to prioritize } \\
\text { demands of higher added } \\
\text { economic segments }\end{array}$ & $\begin{array}{l}\text { More caution in demanding } \\
\text { liberalization as protection of } \\
\text { industry is associated with } \\
\text { national empowerment }\end{array}$ & $\begin{array}{l}\text { More caution in demanding } \\
\text { the maintenance of the status } \\
\text { quo as economic liberalization } \\
\text { empowered the country }\end{array}$ \\
\hline Government Preference & $\begin{array}{l}\text { Parties that hold the } \\
\text { executive power influence } \\
\text { the negotiation }\end{array}$ & $\begin{array}{l}\text { Prevalence of protectionist } \\
\text { positions given that the PT has } \\
\text { links with labor unions and } \\
\text { small farmers }\end{array}$ & $\begin{array}{l}\text { Prevalence of liberalization as } \\
\text { both BJP- and Congress-led } \\
\text { governments took liberalizing } \\
\text { measures in power }\end{array}$ \\
\hline
\end{tabular}

If not these arguments based on institutions, organization of interests, ideas, and government preferences, what thus explains Brazil's and India's national interest in the DDA talks? A hint lies in exploring in further detail institutional factors. Given the centrality of the MRE and the $\mathrm{MoC}$ in defining positions in trade negotiations, the structure of these institutions and their position in the overall architecture of the state may explain why Brazil had offensive interests and India defensive ones. Current institutional arguments, however, face limitations in explaining how state institutions impact the formation of the national interest. The conditions under which domestic factors prevail over international ones remain unclear. In addition, there is no specification of the circumstances in which decision-making leans towards either liberalizing or protectionist interests. Such limitations demands further theoretical developments on how bureaucracies matter in crafting the national interest.

\section{An Alternative Framework: Looking Abroad vs. Looking Inside}

With the considerations above in mind, I henceforth build on the institutional literature to elaborate the looking-abroad/inside typology and its theoretical implications. In doing so, I first examine arguments that conceive institutions as intervening factors that create incentives for societal actors such as interest groups and NGOs. Thereafter, I elaborate the concepts of looking-abroad and looking-inside bureaucracies. 
To identify the conditions under which a given set of interests prevails, a starting point is to apply Tsebelis's (1995 and 2002) veto player theory to trade negotiations. ${ }^{12}$ The theory implies that, the larger the number of actors with veto power, the narrower the set of options available to negotiators. O'Reilly (2005) concludes that a large number of veto players reduce the probability of changes in tariffs. Under such account, international factors and the action of interest groups do not explain trade policy. Nevertheless, in focusing on the number of players who can veto a decision, the theory overlooks a plausible scenario in which that numerous veto players could reach a common position if they share interests.

The recent argument on access points in state bureaucracies has similar limitations. According to this logic, the more points of access in the state lobbies have, the more likely they are to influence policy outcomes as the costs of lobbying decrease (Ehrlich 2011). Although it is parsimonious, the theory ignores the unequal weights different bureaucracies have. Thus, not all bureaucracies that function as access points for lobbying groups are equal in terms of power. The consequences of the asymmetry among bureaucracies are part of the puzzle. For instance, in the case of Brazil, the MRE is expected to have far more weight than other ministries in crafting negotiating positions. So does the MoC in India due to its coordinating role in the trade talks. Therefore, although other bureaucratic units take part in the formation of the national interest, they are neither veto players nor access points through which organized interests could effectively lobby.

A solution for the shortcomings of the veto players and access points theories lies in identifying which sectors of the state are central in international trade negotiations. If a given section of the state has more control over the negotiating agenda than others, such an institution can therefore have more power in defining the national interest. That is the case, for instance, when the executive branch of a democratic government has the prerogative of negotiating international agreements without suffering a constant scrutiny from legislators. According to Lake (1988: 57), in the US, the executive finds itself in a position that enables it to develop foreign policies even against the will of societal actors. Milner (1997) corroborates this argument by arguing the executive branch empowers itself by controlling information related to negotiations. In any country, however, the executive is hardly a unitary actor, having bureaucracies with different degrees of autonomy (Arel-Bundock et al. 2015). While the head of government can be considered the chief negotiator, other officials are more likely

12 See Mansfield and Milner (2012) for an application of this argument on the signature of preferential trade agreements (PTAs). For a non-institutional argument, see Manger 2012. 
to deal with negotiations on a daily basis. Yet, if the executive prevails, it is not necessarily the only set of institutions that define the national interest. In democratic regimes legislators may participate not only in the ratification of agreements, but also in its negotiation. In addition, while there are nodal bureaucracies, certain institutions and actors - such as elected officers in executive and legislative branches - may have the power to define the whole institutional design itself, and, thus, change which section of the state holds the status of nodal bureaucracy.

Therefore, should those institutions and actors be the analytical focus for explaining national interest in trade? The answer is "no" if two assumptions empirically hold. First, both bureaucrats and elected officials can hardly change the existent institutional design: that can be too costly depending on the number of effective veto players and divert political resources from the major goal-negotiating an agreement. In fact, institutional designs are usually inherited from past decisions (Goldstein 1988). Second, if a new institutional design is politically feasible, the shadow of the future might lead policymakers to avoid risk and pursue the desired outcome in negotiations by other means. Institutional changes open room for unintended consequences (Pierson 2000). Thus, a priori there is no need to problematize why a given institutional design exists in a country as long as the same is not modified just because of a specific international negotiation or in function of vested interests.

The discussion above corroborates Miles' Law (1978): decision-making depends on where one sits in the state apparatus. Such proposition follows Allison's (1971: 171) bureaucratic model of decision-making, in which "each player pulls and hauls with the power at his [or her] discretion for outcomes that will advance his [or her] conception of national, organizational, group, and personal interests." Thus, rather than being the consequence of careful rational action, the national interest arises from multiple interactions shaped by pregiven factors, such as the state's institutional design.

Complementing Miles' claim that "where you stand depends on where you sit," I propose that how one sits within a bureaucracy also impacts decision-making. If institutions are not easily changeable, thus one cannot choose where and how to sit when deciding. The perceptions of one who decides looking to the international level first and foremost are different to those of whose focus lies on the domestic one. A focus on the state, in particular the nodal bureaucracy, implies not treating its institutional design as an intervening factor. Instead, the design of domestic institutions have an independent impact on trade positions. That is the case as long as the existence of the institutional design precedes a given trade negotiation and, thus, the definition of the national interest for it. I then expect that, insofar as 
the state formulates foreign policy, it ultimately defines what the national interest means (Allison 1971; Krasner 1978). Yet current accounts leave unanswered why domestic and international levels have different weights in such a process.

Chorev's (2007: 660) concept of fluid divide attempts to overcome such limitation in conceiving both levels as being part of a single field of action. Notwithstanding its sophistication, the argument implies in a different perspective from the typology here advanced. According to Chorev, "institutional arrangements of both states and international organizations affect the relative dominance of the competing factors involved in the process of policymaking." Therefore, the analysis of the institutions involved in trade policy in both domestic and international levels contributes to unfold the logics behind the shifting balance that attributes different weights to national and external constraints. In contrast to Chorev's argument, however, I contend that an institutional perspective can be more parsimonious if focused only on the domestic bureaucracies devoted to international trade negotiations as a departing point to understand interactions between different state sections.

Within such a model, both domestic and international factors are subsumed into a single framework, and it is possible to incorporate constraints that arise from within the bureaucracies themselves independently from societal pressures or foreign limitations. As explained in the previous section, agency shapes institutions, yet the latter evolve in unpredictable ways, opening room for unintended consequences. Such a fact implies that institutional design impacts policymaking independently from other factors as it embeds social action, leading decision-makers to have a given understanding of the conjecture in which negotiation takes place. Out of all these institutions, the nodal bureaucracy responsible for negotiations is the section of the state that matters the most for understanding state's preferences: it controls the agenda of national interest formation and, thus, constrains demands coming from other institutions. In focusing on the nodal bureaucracy and classifying it according to the looking-abroad and looking-inside typology, one can therefore identify the impact of issue-areas not immediately related to the negotiation under analysis.

I thus argue that the weight of domestic and international factors upon decisionmaking depends on the institutional design of the state. This, in turn, determines whether domestic or international embeddedness prevails within a bureaucracy. Originally, the concept of embeddedness focused on the autonomy of the state vis-à-vis private interests in the domestic level (Evans 1995; Hobson 1997). The concept implies that the more embedded a state is, the more sensitive it is to demands from domestic players. For the sake of simplicity, the notion of autonomy can be left aside once the concept of embeddedness is 
converted into domestic embeddedness and contrasted with international embeddedness. They generate the looking-inside and looking-abroad ideal types respectively, with the following consequences: looking-abroad bureaucracies are devoted to international relations in general take into account first and foremost in decision-making foreign constraints, correspondent to the broad world political-economic conjecture; looking-inside bureaucracies focus above all domestic interests (including from other parts of the state, such as the legislative power in democracies) in decision-making given their specialization on traderelated issues. Figure 1 schematizes the argument, representing how each type of bureaucracy finds itself in relation to the domestic and international level.

Figure 1. Looking-abroad and inside bureaucracies and the domestic-international divide

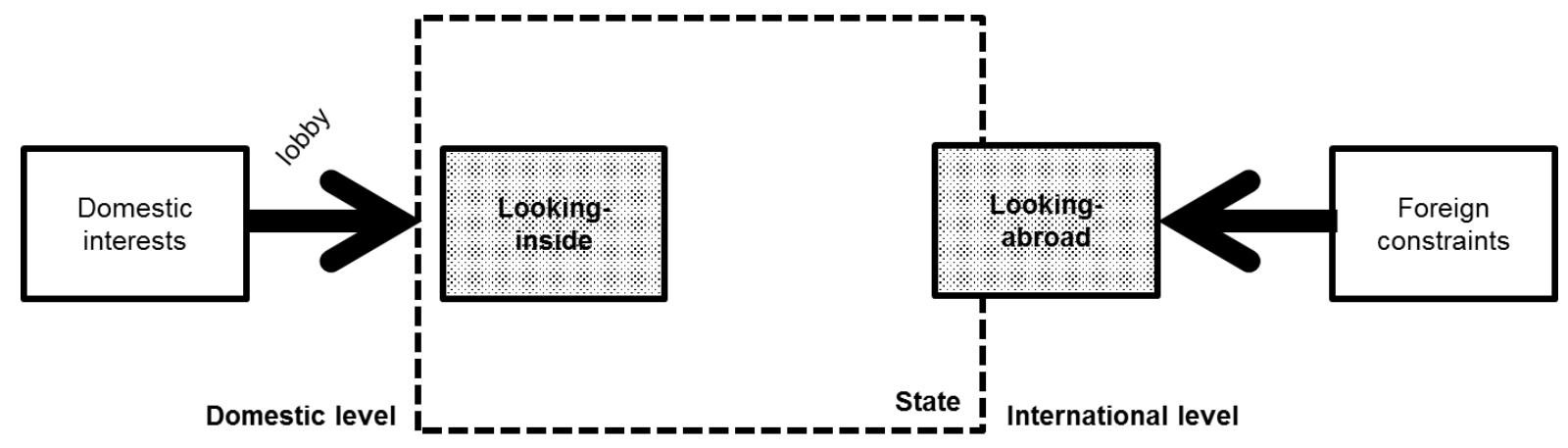

Certainly those are ideal types that may not capture all nuances in variations in the institutional design of decision-making in international trade negotiations throughout all sovereign states. However, the identification of the nodal bureaucracy, followed by the definition of its main characteristic, furnishes basic elements for a more rigorous, systematic explanation of the origins of a country's national interest in trade.

\section{Applying the Framework: Brazil and India in the Doha Round}

In this section, I demonstrate the application of the typology developed above for Brazil and India. The results suggest the nodal bureaucracy is the most relevant institution to the formation of national positions on trade negotiations. In the Brazilian case, in which the MRE looks abroad first and foremost, I also evaluate the prediction that international factors tend to have more importance than domestic ones as the country`s preferences are defined. In turn, India's MoC looks inside as its bureaucrats craft the demands presented at the negotiating table, thus being more subject to domestic constraints.

Out of the 99 interviewees, 43 were involved in negotiations in India, and 56 in Brazil. For each country, I listed potential informants through snowball sampling (Miles and 
Huberman 1994: 28; Sinha 2005: 23). Given limitation of time during fieldwork in each country where most interviews were conducted (Brazil, India, and Switzerland), I set the goal of interviewing at least half of the list, being 50 percent of them bureaucrats from the nodal bureaucracy (MRE in Brazil, and the $\mathrm{MoC}$ in India). From the Brazilian sample, I interviewed 58 percent of the 97 people listed, while in India I managed to talk with 56 percent out of 77 names. Along with this strategy, I formed two major groups of interviewees for each case: half is placed in the nodal bureaucracy, and the other half consists of members of other bureaucracies and market actors from business associations, as well as NGOs. I supplemented the information interviewees provided with archival and secondary sources.

\section{Brazil: a Looking-Abroad Model}

"Insofar as the MRE faces the limits of foreign positions, it is reasonable that the ministry formulates the national demands in a trade negotiation." ${ }^{\prime 13}$ This is how a senior bureaucrat explains the prominent role the Ministry of Foreign Relations played in relation to the DDA talks. As the negotiations evolved, the MRE however had to deal with an increasing number of institutions and non-state actors contributing with policymaking (Cason and Power 2009: 118). Therefore, how was it possible for the MRE to mitigate protectionist demands, such as those from manufacturing sectors, in the formation of the national interest? The answer is straightforward: the ministry retained the prerogative of conducting Brazil's foreign affairs and remained more embedded in the international level than in the domestic arena, defining the national interest based first and foremost based upon the broad international political conjecture. This constrained inputs from other bureaucracies and business segments whose interests that could hinder the use of the DDA as a means of empowering Brazil politically in the world stage. In turn, such a project depended on defending liberalizing positions to weaken Global North's stances on protecting their agricultural markets.

The MRE is reputed to have more autonomy and internal coherence than other parts of the Brazilian state. While diplomats still claim to have a monopoly in defining the national interest, since mid-1990s the MRE receives more and more inputs from other units within the state (Armijo and Kearney 2008). In addition, given the complexities that arise from globalization, diplomats became more receptive to interactions with organized interests as a mean of avoiding misperceptions in negotiations. Those changes occurred, however, while the ministry preserved its status as the nodal bureaucracy for trade negotiations. Given that

${ }^{13}$ Author interview with senior bureaucrat, Brasília. 20 June 2012. 
the MRE perceived the launch of a new multilateral round of trade liberalization as inevitable, the ministry consulted with other bureaucracies and societal organizations in 1999. In July of that year, four months before the Seattle Ministerial Meeting for launching the failed Millennium Round, President Cardoso created the Inter-Ministerial Working Group on International Trade of Goods and Services (GICI). The group focused on liberalization at the multilateral level. ${ }^{14}$ In 2003, the MRE organized a working group dedicated to agriculture with the aim of building consensual positions for the sector, which was the Brazilian focus in the round. ${ }^{15}$ Called the Informal Technical Group (GTI), it included players other than the MRE. ${ }^{16}$ The GTI was built upon the pre-existing connections between the MAPA and market actors. ${ }^{17}$ The group surpassed the GICI as the main forum for formulating Brazil's core positions for the DDA negotiations. As diplomats report, many positions that would later be presented at the negotiations by the Agricultural G-20 were first discussed at the GTI. ${ }^{18}$ Moreover, the MRE contributed to the creation of a private think-tank called ICONE, which improved the negotiators' technical background on agriculture. ${ }^{19}$

A similar approach was taken with regards to industrial sectors. The MRE created a group for Non-Agricultural Market Access (NAMA) themes analogous to the GTI, which focused on agriculture. ${ }^{20}$ Also, at the beginning of 2004, the Permanent Mission in Geneva

14 The GICI was composed by diplomats and members from the ministries of Finance; MDIC; MAPA; Science and Technology; Budget and Public Management; and Environment, as well as the Chamber of Foreign Trade (CAMEX) (Presidência da República 1999). The latter, along with the three first ministries listed, will be analyzed in detail ahead as they remained as relevant players from the state in foreign trade policy as the DDA as the negotiations evolved.

${ }^{15}$ Author interview with bureaucrat, 12 Mar 2012.

${ }^{16}$ Author interview with Luiz Carmona, MAPA bureaucrat, Brasília, 19 June 2012.

17 Author interview with Carlos Cozendey, MRE bureaucrat, Brasília, 26 June 2012; Author interview with Camila Sande, CNA Officer (2009-), Brasília, 27 June 2012.

18 Author interview with bureaucrat, 12 Mar 2012; Author interview with senior bureaucrat, 18 Oct 2012.

19 The ICONE also worked to build positions for the G-20 (Author interview with André Nassar, ICONE Officer, São Paulo, 20 July 2012).

${ }^{20}$ Author interview with market actor, 4 June 2012. 
pressed the FIESP to expand its research capacity on international negotiations. ${ }^{21}$ Diplomats in the Permanent Mission wanted to build critical mass to negotiate NAMA, and, despite initial opposition from top-tier diplomats based in Brasília, the FIESP sent an official to Geneva to work with the Brazilian representatives to the WTO. ${ }^{22}$ The role of FIESP as an informal think-tank for negotiations involving industrial goods was crucial insofar as the MDIC opposed the trade-off that the DDA implied for Brazil. ${ }^{23}$ As the round seemed to be reaching its end, in 2008, the Permanent Mission liaised directly with business associations to discuss the impact of the Swiss Formula (Gallagher 2007, 74-77) for tariff cuts and the selection of tariff lines for the exception list in NAMA. ${ }^{24}$

Apart from the MRE, the MDIC emerged during the DDA timeframe as the most relevant player for the elaboration of positions in foreign trade policy. The MDIC was created in 1999, from the Ministry of Industry and Commerce (MIC), which had historical connections with the industrial sector, including the FIESP and the CNI. Those ties, particularly with the CNI through the CEB, prevailed as the ministry was converted into the MDIC, as part of Cardoso's strategy, launched in his second term (1999-2003), to boost Brazilian exports and to avoid disruptions in the balance of payments (Rodrigues Vieira 2014: 151). MDIC's ministers between 2003 and 2008 talked directly about the DDA with organized interests and entrepreneurs in manufacturing. ${ }^{25}$ Nevertheless, the proposals and studies were submitted to the MRE, which coordinates de facto the formation of positions in the domestic level. ${ }^{26}$ For instance, archives demonstrate that the MDIC sent to the MRE simulations on the effects of tariff cut proposals. Such an exchange indicates that some informational cooperation existed between both bureaucracies, notwithstanding different views on the negotiations (MDIC 2005 and 2006). The MDIC, however, resisted providing

\footnotetext{
${ }^{21}$ Author interview with market actor, 4 June 2012.

${ }^{22}$ Author interview with market actor, 4 June 2012.

23 Author interview with Frederico Meira, FIESP officer (2005-2013), São Paulo, 2 Aug 2011; Author interview with market actor, Brasília, 18 June 2012.

${ }^{24}$ Author interview with senior bureaucrat, Brasília, 15 June 2012.

${ }^{25}$ Author interview with Sérgio Amaral, MDIC's minister (2001-2002), São Paulo, 25 May 2012; Author interview with Luiz Fernando Furlan, MDIC's minister (2003-2006), São Paulo, 2 Aug 2012; Author interview with former bureaucrat, 14 Dec 2011.

${ }^{26}$ Author interview with Welber Barral, MDIC's Secretary of Foreign Trade (2007-2011), Brasília, 18 June 2012.
} 
all the information that the MRE requested to define the limits of the inter-sectorial bargains that the country could offer and accept. ${ }^{27}$ The MDIC was also the main access point for services, demanding positions from business associations in the sector. The interaction with them was enhanced in 2005 with the creation of the Secretary of Commerce and Services. ${ }^{28}$ In spite of being mainly associated with manufacturing and services, the MDIC also received liberalizing demands from sectors that were part of the agribusiness chain, in particular foodprocessing (such as industrialized meat), which falls between the agriculture and industry. ${ }^{29}$

Agribusiness, however, had its main links with the MAPA. As happened between, on the one hand, the heads of the MDIC and, on the other, the industrial sectors, major agricultural producers and organized interests had direct links with the minister of Agriculture. When the round was launched in 2001, Marcus Vinícius Pratini de Moraes, then the minister of Agriculture, talked directly with associations of agro-export sectors inputs to formulate initial positions for the round. ${ }^{30}$ Given the rising importance of commodityexporting for Brazil's foreign trade, the ministry created a Secretary of International Relations to enhance its policymaking capacity in the area. ${ }^{31}$ Small farmers, in turn, had their interests represented by the Ministry of Agrarian Development (MDA). Created in 1999, the ministry only became involved in the DDA negotiations during Lula's government. This was part of a strategy of listening to the views of the small producers that had defensive interests in order to confer more legitimacy on the formation of negotiating positions. ${ }^{32}$ The clearest signal of MDA's incorporation in the process of policymaking in trade negotiations came in 2005, with a Presidential Decree that placed the minister of Agrarian Development in the

27 Author interview with Frederico Meira, FIESP officer (2005-2013), São Paulo, 2 Aug 2011; Author interview with market actor, Brasília, 18 June 2012.

${ }^{28}$ Author interview with bureaucrat, Brasília, 5 July 2012.

${ }^{29}$ Author interview with Welber Barral, MDIC's Secretary of Foreign Trade (2007-2011), Brasília, 18 June 2012. This tended to happen more intensively in the period 2003-2006, when Luiz Fernando Furlan, a food-processing entrepreneur, was ahead of the MDIC.

${ }^{30}$ Author interview with Marcus Vinícius Pratini de Moraes, Minister of Agriculture (19992003), São Paulo, 13 Aug 2011.

${ }^{31}$ Author interview with bureaucrat, Brasília, 20 June 2012.

32 Author interview with bureaucrat, Brasília, 20 June 2012; author interview with Luiz Vicente Facco, CONTAG director, Brasília, 3 July 2012. 
Council of Ministers of the Chamber of Foreign Trade (CAMEX) (Presidência da República 2005), reflecting PT's links with peasant organizations and landless movements.

The CAMEX had been created in 1995, just after Cardoso became President. Initially placed within the presidential office with the goal of acting as a coordination forum in foreign trade policy (WTO 2009: 15), it was transferred to the MDIC in 2001, as the head of the ministry was given the responsibility of presiding over the chamber. Officially, the CAMEX has the prerogative of determining the negotiation directives for international agreements related to trade issues (Presidência da República 2003). The main decision-making body within the chamber is the Council of Ministers, originally formed by the ministers of Development, Industry and Foreign Trade (the chair); of the Civil House (the President's chief-of-staff); Foreign Relations; Finance; Planning, Budget and Administration; and Agriculture (Presidência da República 2001). In spite of officially controlling the CAMEX, the MDIC is far from having the last word on trade negotiations. Neither the ministry nor the chamber was part of the GTI organized to formulate positions in agriculture. ${ }^{33}$ Insofar as the MRE remains in the charge of negotiations, ${ }^{34}$ it retains the coordination position that is legally under CAMEX umbrella. Figure 2 exemplifies the looking-abroad model in Brazil, with international embeddedness prevailing due to MRE stronger linkages with external rather than domestic processes.

Figure 2. A looking-abroad model (Brazil)

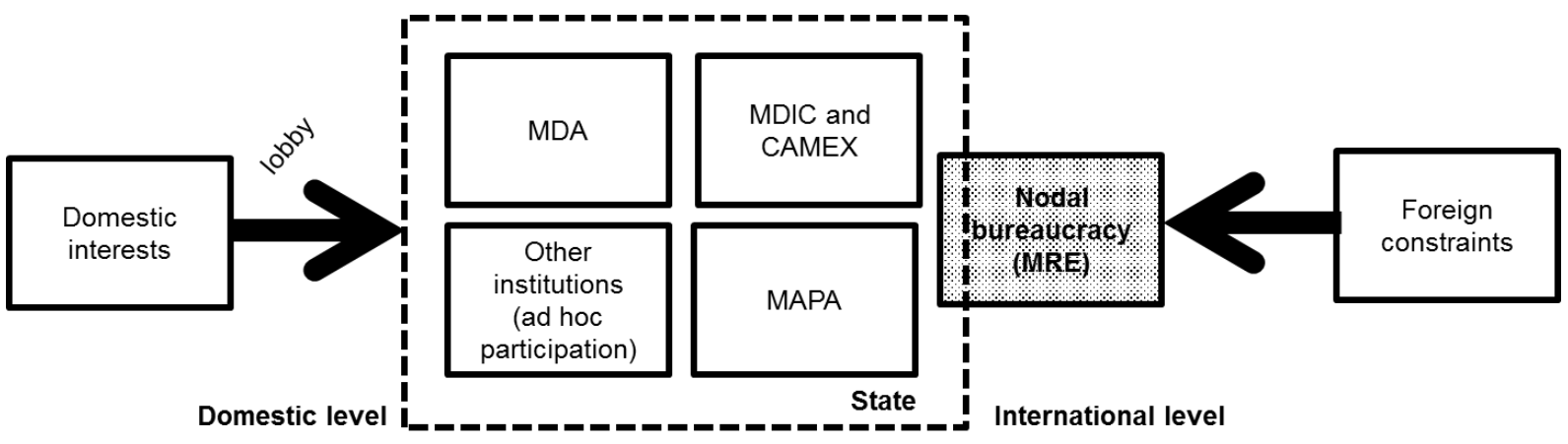

Without the existence looking-abroad institutional design, Brazilian negotiators would hardly have downplayed the demands of protectionist segments as they were organized as an interest group (i.e., CEB and FIESP) and had connections with relevant sections of the state (i.e., MDIC). Within the international conjecture in which negotiations took place, Brazilian diplomacy considered the DDA an opportunity to enhance the country's gains not only in

\footnotetext{
${ }^{33}$ Author interview with Luiz Carmona, MAPA bureaucrat, Brasília, 19 June 2012.

${ }^{34}$ Author interview with Carlos Cozendey, MRE bureaucrat, Brasília, 26 June 2012.
} 
what concerns political status as an emerging power, but also in material terms through the expansion of agricultural exports. At the same time, with active participation within the WTO system, the country could signal to the international society commitment to multilateralism. However, under Lula's government, such a commitment was converted into a means to attempting to enhance leadership among developing countries.

Having been crafted under the perception that the West's power could be softbalanced (Hurrell 2006: 16; Hurrell and Narlikar 2006: 431), ${ }^{35}$ the articulation of the Agricultural G-20 satisfied PT's aspirations to establish deeper relations between Brazil and the Global South (Burges 2009: 160-161), MRE left-wing-leaning bureaucrats, and entrepreneurs who had gained strength with the liberalization of the economy (Mullins 2006: 97). However, that seemed odd under traditional ideas of realpolitik insofar as commodity exporting is hardly associated with state empowerment in the international arena (Gilpin 1981). The FTAA, in turn, which was in the interest of industrial sectors, never came into force in large part thanks for to the Brazilian government negotiating tactic of postponing substantial decisions until the US abandoned the project in 2005. These tactics met part of PT's anti-American stances, yet came about largely due to MRE's looking-abroad institutional design. As a senior bureaucrat summarizes, "the circumstances allowed ourselves to oppose the EU and the US ... In sum, it was a magic moment which allowed us to project ourselves abroad." ${ }^{\text {"36 }}$ Another official goes further and says that "...the conclusion of the round would enhance Brazil's diplomatic prestige in the world." ${ }^{37}$

To summarize, since early 1990's Brazil witnessed the emergence of partisan preferences on foreign policy as well as of state actors other than the MRE in dealing with external affairs and the growing interest of organized groups in external economic relations. The MRE, however, retained its dominant position in defining the national interest in trade talks. As the ministry is embedded more internationally than domestically, it looks first and foremost at foreign constraints when elaborating the national interest in trade.

\section{India: Looking-Inside Above All}

Every Indian bureaucrat interviewed for this research emphasized that they listened to domestic constituencies when crafting the national interest for the DDA. Listening, however,

\footnotetext{
${ }^{35}$ Inteviews, Brasilia, June-July 2012.

${ }^{36}$ Author interview with senior bureaucrat, Brasília, 15 June 2012.

${ }^{37}$ Author interview with senior bureaucrat, Brasília, 6 July 2012.
} 
does not mean accepting actors' demands in crafting the national interest. Nonetheless, there is evidence that, in India, domestic non-state actors and institutions other than the nodal bureaucracy have more weight in policymaking than in Brazil. That is perhaps why India is known in international negotiations as the country that says "no" (Narlikar 2010). After taking into consideration diverse domestic positions, the state always ends up with a narrow set of options for a bargain with its counterparts in the international level. Negotiators are aware of potential veto players and their political strength, such as the large portion of the population which depends on small farming to survive. MoC's domestic embeddedness leads negotiators to prioritize internal factors over external ones as they define the national interest looking inside the country.

India has an exclusive ministry or department for commerce-related issues (including trade negotiations) since its independence in 1947. Since 2000, the MoC is divided into the Department of Commerce (DoC) and the Department of Industrial Policy and Promotion. MoC's bureaucrats involved in the DDA negotiations were not concerned only with WTO issues, but had to handle negotiations of other agreements, such as the preferential trade agreements (PTAs) which India either started negotiating or signed in the 2000s. ${ }^{38}$ Almost everyone working in the $\mathrm{MoC}$ is a career bureaucrat, with the exception of the minister, appointed by the Prime Minister. MoC's bureaucrats come from the Indian Administrative Service (IAS), not from the Indian Foreign Service (IFS), which comprises the diplomats. ${ }^{39}$ Bureaucrats subordinated to the Joint-Director of Trade responsible for the DDA elaborated reports on the sectors. In this process, part of the applied research work-in all negotiating areas, from agricultural to non-agricultural issues - is outsourced, particularly to the thinktanks, all of which already existed when negotiations started in 2001. This phase, as a senior negotiator reports, consists of "a pure academic exercise." 40

${ }^{38}$ Author interview with Rahan S. Ratna, MoC senior bureaucrat (2001-2008), Delhi, 14 Sep 2011; Author interview with MoC senior bureaucrat, Delhi, 7 Sep 2011.

${ }^{39}$ Such a fact, as a senior diplomat comments off the record, has a virtuous contribution to economic diplomacy. That is the case because the IAS members who are allocated at the $\mathrm{MoC}$ have experience in domestic policy. This leads negotiators to be more aware of India's population limits in economic terms than if they had devoted all their careers to international affairs, as the IFS members do.

${ }^{40}$ Author interview with Rahan S. Ratna, MoC senior bureaucrat (2001-2008), Delhi, 14 Sep 2011. 
In parallel to inputs researchers provide, MoC officials receive submissions from domestic societal actors. According to all bureaucrats interviewed, the submissions should be underpinned by technical studies to demonstrate their plausibility and feasibility, as well as their contribution to the national interest. Organized interest groups hire the same think-tanks to which the MoC commissions its own studies. In addition, law firms with a specialization on international issues and university-based academics were hired to produce reports on topics discussed at the DDA talks. ${ }^{41}$ From the international level, the DoC also counts on inputs from the Permanent Mission in Geneva that represents India's positions in the WTO. Those inputs, as bureaucrats report, contributes to the formulation of negotiating stances, yet constraints from the domestic level still matters the most in shaping decisions. It is noteworthy that think-tanks are far from being insulated from the political and economic circles of power in Delhi. In fact, nine out of ten researchers interviewed had already occupied positions in either government or other think-tanks prior to their current position. Many of the confidential think-tank reports are not considered in the final decisions. ${ }^{42}$ Yet their conclusions enable a higher degree of participation and contribution of societal actors to the formulation of the national interest than would have been the case otherwise.

The interactions between organized interests and the $\mathrm{MoC}$, however, are not restricted to the exchange of information on technical studies. Societal actors also lobby bureaucrats through other formal means, such as official submissions in the form of letters and participation on committees on trade-related affairs, and informal channels, including meetings with civil servants and phone calls. ${ }^{43}$ Throughout most of the DDA negotiations, the DoC had two main official bodies through which stakeholders provided inputs on foreign trade policy in general: the Board of Trade and the Export Promotion Board (WTO 2002: 17; WTO 2007a: 21). Until 2004, under the NDA, there was also an Advisory Committee on International Trade composed by both state and non-state actors. ${ }^{44} \mathrm{UPA}^{\prime}$ s ministry of Commerce Kamal Nath, in turn, limited the role of this committee (Sharma 2007: 24). Evidence from interviews in general suggests that it was extinguished in practice after 2004.

\footnotetext{
${ }^{41}$ Author interview with Samir Gandhi, lawyer and consultant, Delhi, 22 Sep 2011.

42 Author interview with consultant, Delhi, 12 Sep 2011.

43 Author interview with T. S. Vishwanath, CII representative in Geneva (2003-2005) and consultant, Delhi, 21 Sep 2011.

${ }^{44}$ Author interview with Bipul Chatterjee, CUTS officer, Delhi, 6 Sep 2011. See also Dhar and Kallummal (2007: 196).
} 
Such a fact, however, does not mean that interactions with non-state actors diminished under the UPA government. The MoC conducted direct consultations with societal actors through the UNCTAD-India project. ${ }^{45}$ In 2006, after the Hong Kong Ministerial, the MoC held 14 consultation meetings with civil society in Indian states. ${ }^{46}$ Under the NDA administration, the ministry held workshops on WTO-issues at sectorial associations and councils (Lok Sabha 2003), and sent bureaucrats to places other than Delhi to hear the demands of societal actors. In partnership with the $\mathrm{MoA}$, the $\mathrm{MoC}$ held four regional meetings in 2001 before the launch of the DDA (Rajya Sabha 2001). The ministry also organized meetings with representatives of state governments, requesting that they establish "cells" (working groups) on WTO issues. After the Doha Ministerial, in 2002 ten out of 35 Indian states and territories had organized such bureaucratic units. ${ }^{47}$ In 2005, the UPA government created the Inter-State Trade Council, composed of chief ministers of the states or state cabinet ministers nominated by chief ministers, representatives from ministries other than the $\mathrm{MoC}$ and government agencies with interest on trade-related issues, and members of industrial associations (MoC 2005).

DoC's officials elaborate positions that inform the national negotiating stances, which are only defined once there is governmental approval. To ensure that the government approves whatever the $\mathrm{MoC}$ defines as corresponding to the national interest, the DoC consults other bureaucracies at the federal level, as well as state-level governments. ${ }^{48}$ Whenever no agreement is reached, then the question goes to the ministerial cabinet, which is made up of political appointees only. However, the set of demands usually only reaches the cabinet once the secretaries from different ministries that have an interest in the negotiations reached a common ground. ${ }^{49}$ Out of all potential constraints that any government in India

\footnotetext{
${ }^{45}$ Author interview with Dr. Abhijit Das, MoC senior bureaucrat (2000-2005) and member of UNCTAD-India Project (2005-2010), Delhi, 12 Sep. 2011.

${ }^{46}$ UNCTAD-India 2010, 17.

47 The states are Andhra Pradesh, West Bengal, Madhya Pradesh, Karnataka, Haryana, Punjab, Tripura, Nagaland. The union territories of Delhi, and of Dadra and Nagar Haveli established WTO cells too (Lok Sabha 2002).

${ }^{48}$ Author interview with Gopal K. Pillai, Secretary of Commerce (2004-2009), Delhi, 16 Sep 2011; author interview with former senior bureaucrat, 26 Sep 2011.

${ }^{49}$ Author interview with Gopal K. Pillai, Secretary of Commerce (2004-2009), Delhi, 16 Sep 2011; author interview with former senior bureaucrat, 26 Sep 2011.
} 
faces in negotiating trade deals, concerns with food security and livelihood are paramount, insofar as at least two thirds of all Indians still lived in rural areas at the time the DDA was launched. Since the 1960s farmers have been gaining influence at the federal government as agriculturalists became the single largest professional group among lower house Members of the Parliament (MPs) (Varshney 1993: 180-184). "There are 600 million poor farmers who depend on subsistence agriculture... In a democracy, any government that comes to power will have to protect their interests," summarizes a former senior bureaucrat. ${ }^{50}$

Nevertheless, small, protectionist farmers channel their demands not only through the Parliament. In fact, there was unanimous agreement among interviewees that, in trade matters, the MoA consists of the second-most influential bureaucracy after the MoC. According to a former senior official, MoA's bureaucrats usually go to Geneva along with MoC's members to follow negotiations on agricultural issues. ${ }^{51}$ Whereas MoC's officials argue that they are in the pursuit of the national interest no matter what it means, the MoA has a well-established stance that in the view of its bureaucrats represents the nation: the current structure of agriculture in India must be preserved because the small peasantry needs to be protected. ${ }^{52}$ The MoA, as a senior bureaucrat reports, does not want any trade-off that involves agriculture, as would be the case with liberalization in the services sector. ${ }^{53}$ If there is negotiation on some of the issues in agriculture, the MoA takes a position. ${ }^{54}$ In this process, not only positions of MoA's bureaucrats are expressed, but also those of state governments. ${ }^{55}$ It happens because they are responsible for developing and implementing agricultural policies, and act in practice as a lobby on the behalf of farmers. Moreover, the ministry is

\footnotetext{
${ }^{50}$ Author interview with former senior bureaucrat, 26 Sep 2011.

${ }^{51}$ Author interview with Dr Biswajit Dhar, RIS director and former negotiator, Delhi, 12 Sep 2011; author interview with former senior bureaucrat, 20 Mar 2012.

52 The Ministry of Food and Civil Supplies, currently Ministry of Consumer Affairs, Food and Public Distribution, contributed significantly to support this view as well (Author interview with Ajay Sahai, FIEO's director-general, Delhi, 19 Sep 2011).

${ }^{53}$ Author interview with senior bureaucrat and former negotiator, Delhi, 7 Oct 2011.

${ }^{54}$ Author interview with Ajay Sahai, FIEO's Director-General, Delhi, 19 Sep 2011.

55 Author interview with Gopal K. Pillai, MoC Secretary of Commerce (2004-2009), Delhi, 16 Sep 2011.
} 
usually under the control of a powerful politician at the regional level, ${ }^{56}$ thus conferring additional strength to the demands from states and territories.

In addition to the MoA, the MEA gained momentum on economic affairs since economic liberalization in the $1990 \mathrm{~s},{ }^{57}$ as part of India's emphasis on relations with its Asian neighbors. With the increasing international integration of markets, trade negotiations expanded their political-strategic dimension, ${ }^{58}$ thus demanding more inputs from diplomats than during the ISI period. ${ }^{59}$ In the words of a very experienced policymaker, "commerce became as important as political diplomacy". ${ }^{60}$ This does not mean, however, that the MEA posits any challenge to MoC's status as nodal bureaucracy for trade negotiations. That said, the MEA participates in the elaboration of national interests at the cabinet level ${ }^{61}$. Moreover, as current and former senior officials from both MEA and MoC report, for India multilateral negotiations do not arise as much international political issues as bilateral and regional economic treaties do. ${ }^{62}$ Once the government established the major guidelines for the DDA negotiations and the Indian participation in the multilateral system of trade, explicit political issues did not arise. Such a fact reduces the need for MEA's participation in WTO-related affairs. Nonetheless, the MEA also has up to three officials ${ }^{63}$ (including the deputy head)

\footnotetext{
${ }^{56}$ Author interview with consultant, Delhi, 12 Sep 2011.

${ }^{57}$ Sinha (2007: 1193) suggests that before 1998 the MEA had as much power as the MoC in crafting positions for multilateral trade negotiations. Any of the Indian officials I interviewed,
} however, support such a view.

${ }^{58}$ Author interview with Dr. Sachin Chaturvedi, RIS Researcher, Delhi, 26 Sep 2011; Author interview with a former senior bureaucrat, Delhi, 17 Sep 2011; Author interview with thinktank researcher, Delhi, 21 Sep 2011.

${ }^{59}$ Author interview with B. K. Zutshi, Indian Ambassador to the GATT (1989-1994), Delhi, 14 Sep 2011.

${ }^{60}$ Author interview with former senior bureaucrat, Delhi, 17 Sep 2011.

${ }^{61}$ Author interview with Ujal Singh Bhatia, Indian Ambassador to the WTO (2004-2009), Delhi, 7 Sep 2011.

62 Author interview with think-tank researcher, Delhi, 21 Sep 2011; author interview with former MEA senior bureaucrat, Delhi, 23 Sep 2011.

63 Author interview with MoC senior bureaucrat, Delhi, 7 Sep 2011; author interview with former senior bureaucrat, Delhi, 17 Sep 2011; Author interview with former senior bureaucrat, 26 Sep 2011; Author interview with MoC senior bureaucrat, 21 Mar 2012. 
constantly allocated in the Permanent Mission to the WTO in Geneva, which suggests that the IFS monitored the DDA. In fact, as Brazilian diplomats, Indian negotiators also pursued political prestige for their country in the world stage while negotiating the DDA. In leading the G-33, India pursued not only special treatment for its own peasants. The country also heralded itself as the champion of the poor farmers of the world and echoed its traditional role as a leader of the developing world, notwithstanding the existence of export interests among part of its farmers ${ }^{64}$ and the demand for liberalization in ICT services.

Such facts prompt the question whether India's national interest in the DDA actually steamed from its domestically-embedded institutional design, being instead a consequence of - as Brazil did - a quest for political status as a rising power through the leadership of significant part of the Global South. "There is closed interaction with the MEA, but the way we formulate our positions is through a much wider consultative process, with all ministries, all stakeholders, and the states", 65 explains a former ambassador to Geneva. One can therefore say that, while India's protectionist stances served diplomatic purposes (Rodrigues Vieira 2016), they would not have acquired salience without an institutional design that prioritizes domestic inputs in the formation of the national interest. Figure 3 summarizes the institutional design of the formation of the national interest in trade negotiations in India, with the MoC acting as the nodal bureaucracy. In contrast to the MRE in Brazil, the MoC is more embedded in the domestic level than the international one.

Figure 3. A looking-inside model (India)

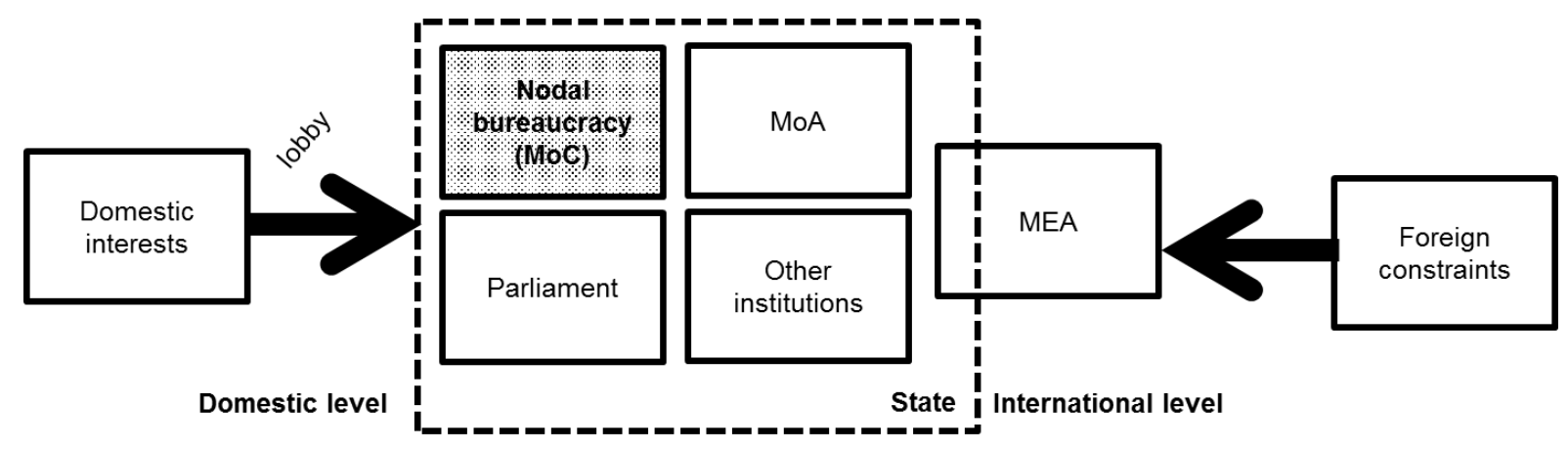

India's pursuit of PTAs also reflects the prevalence of domestic embeddedness. PTAs represent a second-best alternative for sectors that could benefit from further trade

\footnotetext{
${ }^{64}$ WTO 2002.

${ }^{65}$ Author interview with Ujal Singh Bhatia, Indian Ambassador to the WTO (2004-2009), Delhi, 7 Sep 2011.
} 
liberalization. The DDA framework limited further economic openness as the conclusion of negotiations implied in the reducing policy space in agriculture. The bilateral and regional track relied on the active support of market actors linked to the $\mathrm{MoC}$, yet needed the implicit approval of the MEA based on geopolitical considerations. ${ }^{66}$ For instance, while the MoC supports the advancement of economic relations with Pakistan, the MEA has a more cautious approach vis-à-vis the Indian neighbor given the longstanding military-territorial disputes between both countries. ${ }^{67}$

To conclude, external factors in the economy and the international political dynamics cannot explain India's positions with regards to the DDA. The configuration of power in the international level (Hurrell and Narlikar 2006; Rodrigues Vieira 2016), however, reinforced the protectionist trend that emerges from the fact that $\mathrm{MoC}$ coordinates the formulation of negotiating stances. As the $\mathrm{MoC}$ is embedded more domestically than internationally, it formulates the national interest in trade negotiations looking inside, paying attention not only to organized interests, but also to the immediate demands of the government and MPs whose interest is to remain in power and other state bureaucracies. Consequently, protectionist demands, in particular from agriculture, overweight liberalizing ones.

\section{Conclusion}

In this article, I argued that the design of the institutions involved in trade negotiations decisively impacts the formation of the national interest on such issue-area. As bureaucrats craft the national interest, they are subject to constraints that have different weights on decision-making. The prevalence of international or domestic factors depends on the configuration of the state bureaucracy that coordinates policymaking in a negotiation, gathering domestic demands white representing the state abroad in the talks. If the nodal bureaucracy is in charge of foreign policy, international embeddedness prevails over domestic embeddedness. So does the impact of external factors over internal ones in policymaking. In turn, the opposite happens whenever the bureaucracy is dedicated to traderelated issues only. The argument was built upon Brazil's and India's cases in WTO's DDA between 2003 and 2008.

66 Author interview with Dr Kasturi Das, RIS researcher, Delhi, 16 Sep 2011; author interview with a former MEA senior bureaucrat, Delhi, 23 Sep 2011.

${ }^{67}$ Author interview with think-tank researcher, Oxford, 27 Mar 2013. 
In Brazil, the MRE is the nodal bureaucracy, whereas in India the MoC conducts negotiations. The latter represents a case of looking-inside bureaucracy, then being more subject to domestic rather than to international forces. In turn, the former consists of a looking-abroad bureaucracy. As this variation in institutional design precedes the preferences of organized interests, bureaucrats, and politicians, the ideal types looking-abroad and looking-inside explain the formation of different notions of national interest in each case. Being domestically embedded, the $\mathrm{MoC}$ ended up balancing demands from sectors with opposed interests, creating space for the demands of small farmers, which were not organized as a typical interest group. The MRE, however, is internationally embedded, having thus viewed the DDA negotiations as a means of enhancing Brazil's prestige abroad rather than prioritizing the demands of protectionist segments.

Two main research avenues can be explored based on the ideal-types I developed. One consists of applying the looking-abroad/inside typology to other cases within the context of the DDA. Potential cases are the US, Argentina, and Canada, which, as Brazil and India, are very active at the multilateral system of trade and have a mix of liberalizing and protectionist economic sectors within a federal institutional setting. The US legislative approved from time to time since 1974 the Trade Promotion Authority (TPA), which delegates to the President the power of negotiating agreements while in practice assuring its ratification. Yet, rather than granting full autonomy to the President-who then appoints a Trade Representative (USTR) to negotiate on the government's behalf-, TPA makes the executive more accountable vis-à-vis legislators in the negotiation of trade agreements (O'Halloran 1993; WTO 2008). The American institutional design, with the USTR acting as the nodal bureaucracy, therefore represents a looking-inside type. In fact, during the TPA mandate that lasted between 2002 and 2007 the USTR to defend in the DDA liberalizing positions (dominant at the beginning of the talks) as well as protectionist ones (which stated to gain prominence after Brazil and India organized the Agricultural G-20 in 2003).

Argentina, in turn, shows the possibility of hybrid cases as the Ministry of Foreign Affairs, which was in charge of negotiations, defined positions in coordination with the Ministry of Economy (WTO 2007b). Both form the nodal bureaucracy de facto, as they are in a horizontal relationship with each other, contrasting to MRE higher status vis-à-vis the MDIC within the Brazilian state. The fact that Argentina's positions were heavily influenced by protectionist industrial lobbies suggests that domestic constraints prevail if a hybrid nodal bureaucracy is in place. Canada's then Department of Foreign Affairs, and International Trade provides another case of hybrid nodal bureaucracy that nonetheless was separated de 
jure between 2003 and 2006 into the Foreign Affairs Canada and the International Trade Canada, the latter being in charge of trade negotiations (Kukucha 2009: 90). Given that the country kept pursuing cautious liberalizing stances during that period, such a case may falsify the theory here developed, yet requires further investigation to verify whether the department was de facto fragmented.

Future research could also explore in more detail cross-temporal interactions inside the state, particularly between executive and the legislative institutions, including in areas other than trade. Such interactions may also affect the formation of the national interest that either reinforce or contradict the impact of the looking-abroad/inside ideal types. In India, for instance, such analysis could explain the variation in the negotiating demands of the NDA government (2001-2004) and the UPA administration (2004-2014). Notwithstanding the constant concern with the fate of small farmers, the overweight the UPA attributed to the defensive G-33 suggests that more than a change in rhetoric happened between the administrations. Likewise, even when a country negotiates a treaty primarily looking outside, as happened in Brazil, there might be implicit limits that come from procedures of ratifying international agreements.

International phenomena are subject to multiple influences, being hardly the outcome of a chain of deliberate rational decisions only. Institutions, thus, have an independent effect on the process of crafting national preferences and possibly in absorbing external influence, including in process of international diffusion. As institutional design do not necessarily reflect the choices of those who participate in policymaking, but a previous political settlement crystalized in the form of institutional design, bureaucrats and politicians usually have no better choice than conforming themselves to the environment in which they are embedded. The same design determines whether bureaucrats will be primarily subject to international or domestic factors as they elaborate decisions, including the definition of the national interest in trade negotiations. 


\section{References}

Acharya, Shankar. 2002. "Macroeconomic Management in the Nineties." Economic and Political Weekly 37 (16): 1515-1538.

Allison, Graham T. 1971. Essence of Decision: Explaining the Cuban Missile Crisis. Boston: Little, Brown.

Armijo, Leslie, and Christine Kearney. 2008. "Does Democratization Alter the Policy Process? Trade Policymaking in Brazil.” Democratization 15 (5): 991-1017.

Arel-Bundock, Vincent, James Atkinson, and Rachel Augustine Potter. 2015. "The Limits of Foreign Aid Diplomacy: How Bureaucratic Design Shapes Aid Distribution.” International Studies Quarterly 59 (3): 544-556.

Ban, Cornel. 2013. "Brazil's liberal neo-developmentalism: New paradigm or edited orthodoxy?" Review of International Political Economy 20 (2): 298-331.

Beach, Derek and Rasmus Brun Pedersen. 2013. Process-Tracing Methods: Foundations and Guidelines. Ann Arbor: University of Michigan Press.

Blagden, David. 2016. Induction and Deduction in International Relations: Squaring the Circle between Theory and Evidence. International Studies Review. At: http://isr.oxfordjournals.org/content/early/2016/04/21/isr.viw004, accessed May 12, 2015.

Bresser-Pereira, Luiz Carlos. 2009. Developing Brazil: Overcoming the Failure of the Washington Consensus, Boulder: Lynne Rienner.

Burges, Sean W. 2009. Brazilian Foreign Policy after the Cold War. Gainesville: University Press of Florida.

Carpenter, Daniel P. 2001. The Forging of Bureaucratic Autonomy: Reputations, Networks, and Policy Innovation in Executive Agencies, 1862-1928. Princeton: Princeton University Press.

Cason, Jeffrey W., and Timothy J. Power. 2009. "Presidentialization, Pluralization, and the Rollback of Itamaraty: Explaining Change in Brazilian Foreign Policy Making in the Cardoso-Lula Era”. International Political Science Review 30 (2): 117-140.

Census of India. 2011. Rural Urban Distribution of Population (Provisional Population Totals. At http://censusindia.gov.in/2011-provresults/paper2/data_files/india/Rural_Urban_2011.pdf, accessed February 28, 2015. 
Chorev, Nitsan. 2007. "A fluid divide: Domestic and international factors in US trade policy formation." Review of International Political Economy 14 (4): 653-89.

Dhar, Biswajit, and Murali Kallummal. 2007. "Trade Policy Off the Hook: The Making of Indian Trade Policy since the Uruguay Round.” In Mark Halle and Robert Wolfe, eds., Process Matters: Sustainable Development and Domestic Trade Transparency. Winnipeg, MB: International Institute for Sustainable Development.

Ehrlich, Sean D. 2011. Access Points: an Institutional Theory of Policy Bias and Policy Complexity. Oxford and New York: Oxford University Press.

Evans, Peter. 1995. Embedded Autonomy: States and Industrial Transformation, Princeton, NJ: Princeton University Press.

Evans, Peter, Dietrich Rueschemeyer, and Theda Skocpol. 1985. Bringing the State Back In, Cambridge: Cambridge University Press.

Farrell, Henry, and Abraham L. Newman. 2014. "Domestic Institutions beyond the NationState: Charting the New Interdependence Approach.” World Politics, 66 (2): 331-363.

Faure, Andrew M. 1994. "Some Methodological Problems in Comparative Politics.” Journal of Theoretical Politics 6 (3): 307-322.

Gallagher, Kevin P. 2007. "Understanding developing country resistance to the Doha Round.” Review of International Political Economy 15 (1): 62-85.

George, Alexander L., and Andrew Bennett. 2005. Case Studies and Theory Development. Cambridge, MA, and London, UK: MIT Press.

Gilpin, Robert. 1981. War and Change in World Politics. Cambridge: Cambridge University Press.

Goldstein, Judith. 1988. "Ideas, Institutions, and American Trade Policy." International Organization 42 (1): 179-217.

Goldstein, Judith, and Robert O. Keohane. 1993. "Ideas and Foreign Policy: An Analytical Framework." In Judith Goldstein, and Robert O. Keohane, eds., Ideas and Foreign Policy: Beliefs, Institutions, and Political Change. Ithaca, NY, and London, UK: Cornell University Press.

Hobson, John M. 1997. The Wealth of States: A Comparative Sociology of International Economic and Political Change. Cambridge: Cambridge University Press. 
Hopewell, Kristen. 2013. "New Protagonists in Global Economic Governance: Brazilian Agribusiness at the WTO.” New Political Economy 18 (4): 602-23.

Hopewell, Kristen. 2015. "Different Paths to Power: The Rise of Brazil, India and China at the WTO." Review of International Political Economy 22 (2): 311-338.

Hurrell, Andrew, and Amrita Narlikar. 2006. "A New Politics of Confrontation? Brazil and India in Multilateral Trade Negotiations." Global Society 20 (4): 415-433.

Ikenberry, John. 1988. "Conclusion: an Institutional Approach to American foreign Economic Policy.” International Organization 42 (1): 219-243.

Kohli, Atul. 2009. Democracy and Development in India: from Socialism to Pro-Business. New Delhi and Oxford: Oxford University Press.

Kukucha, Christopher J. 2009. The Provinces and Canadian Foreign Trade Policy. Vancouver: University of British Columbia Press.

Krasner, Stephen D. 1978. Defending the National Interest: Raw Materials Investments and U.S. Foreign Policy, Princeton, NJ: Princeton University Press.

Lake, David A. 1988. Power, Protection, and Free Trade: International Sources of U.S. Commercial Strategy, 1887-1939, Ithaca, NY: Cornell University Press.

Lok Sabha. 2002. "Unstarred Question No 2062: Establishment of WTO Cells." At http://164.100.47.132/LssNew/psearch/QuestionArchive.aspx, accessed October 1, 2011.

Lok Sabha. 2003. "Starred Question N ${ }^{\circ}$ 290: WTO Negotiations for Agricultural Trade." At http://164.100.47.132/LssNew/psearch/QuestionArchive.aspx, accessed October 1, 2011.

Mancuso, Wagner Pralon, and Amâncio Jorge de Oliveira. 2006. "Abertura Econômica, Empresariado e Política: Os Planos Doméstico e Internacional.” Lua Nova 69: 147-172.

Manger, Mark S. 2012. "Vertical Trade Specialization and the Formation of North-South PTAs". World Politics 64 (4): 622-658.

Mansfield, Edward D., and Helen V. Milner. 2012. Votes, Vetoes, and the Political Economy of International Trade Agreements. Princeton, NJ, and Oxford: Princeton University Press.

MDIC. 2005. Ofício no. 114/SECEX, com Nota Técnica DEINT no.40/2005, de 16 de março (Box XCOI - Jan/Dez 2005). Brasília: Ministério das Relações Exteriores. 
MDIC. 2006. Ofício no. 168/SECEX, com Nota Técnica DEINT no. 87/2006, de 14 de novembro (Box XCOI - Jan/Dez 2006). Brasília: Ministério das Relações Exteriores.

Miles, R. E. 1978. “The origin and meaning of Miles' law.” Public Administration Review, 38 (5): 399-403.

Miles, Matthew B., and Michael Huberman. 1994. Qualitative Data Analysis: An Expanded Sourcebook. Thousand Oaks, CA: Sage Publications.

Milner, Helen V. 1997. Interests, Institutions, and Information: Domestic Politics and International Relations. Princeton, NJ: Princeton University Press.

MoC. 2005. Order No. 01/94/180/438/AM05/PRU. Subject: Constitution of Inter-State Trade Council (June 24). At http://dgftcom.nic.in/exim/2000/interstate.htm, accessed February $28,2015$.

Mukherji, Rahul. 2013. "Ideas, interests, and the tipping point: Economic change in India." Review of International Political Economy 20 (2): 363-389.

Narlikar, Amrita. 2008. "India and the World Trade Organization." In Steve Smith, Amelia Hadfield, and Tim Dunne, eds., Foreign Policy: Theories, Actors, Cases. Oxford: Oxford University Press.

Narlikar, Amrita. 2010. New Powers: How to Become One and How to Manage Them. London: Hurst.

Narlikar, Amrita. 2013. "India's Trade Politics: Continuity and Change.” In Oluf Langhelle, ed., International Trade Negotiations and Domestic Politics: The Intermestic Politics of Trade Liberalization. Abingdon, UK, and New York: Routledge.

Narlikar, Amrita, and Diana Tussie. 2004. "The G20 at the Cancun Ministerial: Developing Countries and Their Evolving Coalitions in the WTO.” World Economy 27 (7): 947-966.

Narlikar, Amrita, and Rorden Wilkinson. 2004. "Collapse at the WTO: a Cancun PostMortem." Third World Quarterly 25 (3): 447-460.

Narlikar, Amrita, and Pieter Van Houten. 2010. "Know the Enemy: Uncertainty and Deadlock in the WTO.” In Amrita Narlikar, ed., Deadlocks in Multilateral Negotiations. Cambridge: Cambridge University Press.

Olson, Mancur. 1971. The Logic of Collective Action: Public Goods and the Theory of Groups. Cambridge, MA: Harvard University Press. 
O’Halloran, Sharyn. 1993. "Congress and Foreign Trade Policy.” In Randall B. Ripley and James M. Lindsay, eds., Congress Resurgent: Foreign and Defense Policy on Capitol Hill. Ann Arbor: The University of Michigan Press.

O’Reilly, Robert F. 2005. "Veto Points, Veto Players, and International Trade Policy." Comparative Political Studies 38 (6): 652-675.

Pierson, Paul. 2000. "The Limits of Design: Explaining Institutional Origins and Change.” Governance 13 (4): 475-499.

Presidência da República. 1999. Decreto de 10 de Junho: Cria, no âmbito do Ministério das Relações Exteriores, o Grupo Interministerial de Trabalho sobre Comércio Internacional de Mercadorias e de Serviços, e dá Outras Providências. At http://www2.camara.leg.br/legin/fed/decret_sn/1999/decreto-8-10-junho-1999-377585publicacaooriginal-1-pe.html, accessed February 28, 2015.

Presidência da República. 2001. Decreto $N^{o} 3.981$, de 24 de outubro de 2001: Dispõe sobre a CAMEX - Câmara de Comércio Exterior, do Conselho de Governo, e dá outras providências. At http://www.planalto.gov.br/ccivil_03/decreto/2001/D3981.htm, accessed February 28, 2015.

Presidência da República. 2003. Decreto $N^{o}$ 4.732, de 10 de Junho de 2003: Dispõe sobre a Câmara de Comércio Exterior-CAMEX, do Conselho de Governo. At http://www.planalto.gov.br/ccivil_03/decreto/2003/D4732.htm, accessed February 28, 2015.

Presidência da República. 2005. Decreto $N^{o}$ 5.453, de 2 de Junho de 2005: Dá nova redação a dispositivos do Decreto no 4.732, de 10 de junho de 2003, que dispõe sobre a Câmara de Comércio Exterior-CAMEX, do Conselho de Governo. At http://www.planalto.gov.br/ccivil_03/_Ato2004-2006/2005/Decreto/D5453.htm, accessed February 28, 2015.

Putnam, Robert. 1988. "Diplomacy and Domestic Politics: the Logic of Two-Level Games." International Organization 42 (3): 427-460.

Rajya Sabha. 2001. "Starred question $N^{\circ}$ 471: WTO Negotiations on Agriculture." At http://164.100.47.5/qsearch/qsearch.aspx, accessed October 1, 2011. 
Rodrigues Vieira, Vinícius. 2014. "Is Politics Behind Trade? The Impact of International Trends and Diplomatic Action on Brazil's Exports during Globalisation.” Bulletin of Latin American Research 32 (2): 140-157.

Rodrigues Vieira, Vinícius. 2016. "Beyond the Market: the Global South and the WTO's Normative Dimension.” International Negotiation 21(2): 266-293.

SEADE. 2012. Participação do Estado de São Paulo no Valor Adicionado Bruto do Brasil a preços básicos, segundo setores e subsetores de atividade econômica, Estado de São Paulo, 2010-2011. At http://produtos.seade.gov.br/produtos/pib/, accessed February 28, 2015.

Shaffer, Gregory, Michelle Ratton Sanchez Badin, and Barbara Rosenberg. 2008. The Trials of Winning at the WTO: What Lies Behind Brazil's Success. Cornell International Law Journal 41 (2): 383-502.

Sharma, Shefali. 2007. India and the Agreement on Agriculture: Civil Society and Citizens' Engagement. IDS Working Paper 278. Brighton: Institute of Development Studies.

Sherman, Richard. 2002. "Delegation, Ratification, and U.S. Trade Policy: Why Divided Government Causes Lower Tariffs.” Comparative Political Studies 35 (10): 1171-1197.

Sinha, Aseema. 2005. The Regional Roots of Developmental Politics in India: a Divided Leviathan. Bloomington; Indianapolis: Indiana University Press.

Sinha, Aseema. 2007. "Global Linkages and Domestic Politics: Trade Reform and Institution Building in India in Comparative Perspective." Comparative Political Studies 40 (10): 1183-1210.

Sikkink, Kathryn. 1991. Ideas and Institutions: Developmentalism in Brazil and Argentina, Ithaca and London: Cornell University Press.

Tarrow, Sidney. 2010. "Bridging the Quantitative-Qualitative Divide”. In Henry E. Brady and David Collier, eds., Rethinking Social Inquiry: Diverse Tools, Shared Standards. Lanham: Rowman and Littlefield.

UNCTAD-India. 2010. Strategies and Preparedness for Trade and Globalization in India: Key Outcomes of the Project. Delhi: UNCTAD, MoC, and DFID.

Van Evera, Stephen. 1997. Guide to Methods for Students of Political Science. Ithaca and London: Cornell University Press. 
Varshney, Ashutosh. 1993. "Self-Limited Empowerment: Democracy, Economic Development and Rural India.” Journal of Development Studies 29 (4): 177-215.

World Bank. 2010. "World Development Indicators." At http://esds.mcc.ac.uk/wds_wb/ReportFolders/reportFolders.aspx?sCS_referer=\&sCS_Cho senLang=en, accessed July 16, 2014.

WTO. 2002. Trade Policy Review: Report by the Secretariat-India (WT/TPR/S/100). At https://docs.wto.org/dol2fe/Pages/FE_Search/FE_S_S006.aspx?Query=((\%20@ Title=\%2 0india)\%20or\%20(@CountryConcerned=\%20india))\%20and\%20(\%20(\%20@ Symbol=\% $20 \mathrm{wt} / \mathrm{tpr} / \mathrm{s} / * \% 20)) \&$ Language $=$ ENGLISH $\&$ Context=FomerScriptedSearch \&languageUIC hanged=true\#, accessed February 28, 2015.

WTO. 2007a. Trade Policy Review: Report by the Secretariat-India (WT/TPR/S/182). At https://docs.wto.org/dol2fe/Pages/FE_Search/FE_S_S006.aspx?Query=((\%20@Title=\%2 0india)\%20or\%20(@CountryConcerned=\%20india) $) \% 20$ and\%20(\%20(\%20@ Symbol=\% $20 \mathrm{wt} / \mathrm{tpr} / \mathrm{s} / * \% 20)) \&$ Language $=$ ENGLISH $\&$ Context=FomerScriptedSearch $\&$ languageUIC hanged=true\#, accessed February 28, 2015.

WTO. 2007b. Trade Policy Review: Report by the Secretariat-Argentina (WT/TPR/S/176). At

https://docsonline.wto.org/dol2fe/Pages/FE_Search/FE_S_S006.aspx?Query=((@ Symbol $=\% 20 \mathrm{wt} / \mathrm{tpr} / \mathrm{s} / *) \% 20$ and $\% 20(\% 20 @$ Title=\%20argentina\%20))\&Language=ENGLISH\& Context=FomerScriptedSearch\&languageUIChanged=true\#, accessed February 28, 2015. WTO. 2008. Trade Policy Review: Report by the Secretariat-US (WT/TPR/S/200). At https://www.wto.org/english/tratop_e/tpr_e/s200-02_e.doc, accessed February 28, 2015.

WTO. 2009. Trade Policy Review: Report by the Secretariat-Brazil (WT/TPR/S/212). At https://docs.wto.org/dol2fe/Pages/FE_Search/FE_S_S009-

DP.aspx ?language $=E \&$ CatalogueIdList $=118423,117449,116768,69487,72511,66569,442$ 87,2296,16131,36240\&CurrentCatalogueIdIndex=5\&FullTextSearch=, accessed February 28, 2015. 